\title{
BACTERIA OF FECAL ORIGIN IN MANGROVE OYSTERS (CRASSOSTREA RHIZOPHORAE) IN THE COCÓ RIVER ESTUARY, CEARÁ STATE, BRAZIL
}

\author{
Ana I. M. Silva1; Regine H. S. F. Vieira ${ }^{1 *}$; Francisca G. R. Menezes ${ }^{2}$; Antonio A. Fonteles-Filho ${ }^{1}$; Regina C.O. Torres ${ }^{3}$; \\ Ernani S. Sant'Anna ${ }^{3}$
}

\begin{abstract}
${ }^{1}$ Instituto de Ciências do Mar, LABOMAR, Universidade Federal do Ceará, Fortaleza, CE, Brasil; ${ }^{2}$ Mestranda do Curso de Ciências Marinhas Tropicais, LABOMAR; ${ }^{3}$ Departamento de Ciência e Tecnologia de Alimentos, Universidade Federal de Santa Catarina, Florianópolis, SC, Brasil.
\end{abstract}

Submitted: June 24, 2003; Returned to authors: November 12, 2003; Approved: May 20, 2004.

\begin{abstract}
This study was aimed at evaluating the microbiological quality of mangrove oysters (Crassostrea rhizophorae), collected at a natural oyster bed in the estuary of Cocó river (Fortaleza, Ceará, Brazil). MPN values were used for estimating the total (TC) and fecal (FC) coliforms and Enterococcus spp. TC and FC MPN values in the whole muscle and intervalve liquid ranged from $<1.8$ to $>1,600 / \mathrm{g}$ and from $<1.8$ to $920 / \mathrm{g}$, respectively. The MPN estimates for Enterococcus spp. were between $<3.0$ and $>1,100 / \mathrm{g}$. No correlation was found between the physico-chemical parameters (temperature, salinity and $\mathrm{pH}$ ) of the surrounding water and the bacteriological contamination levels found in the tested oysters. The only correlation found was between TC and FC values. Enterococcus spp. strains were isolated and subjected to biochemical tests for species identification. The capacity of those strains for production of a bacteriocin-like inhibitory substance was tested using the Escherichia coli strain ATCC 25922 as a testing organism. Only one, E. faecalis, out of 121 Enterococcus strains tested, presented the inhibitory activity.
\end{abstract}

Key words: oyster, total and fecal coliforms, enterococci, bacteriocins

\section{INTRODUCTION}

The ingestion of bivalve mollusks has been frequently associated with food-related infections diseases $(12,19)$. Due to health-hazards inherent to its consumption, many countries developed regulations based on the microbiological analysis of water and/or the shellfish's flesh itself. Most of these regulations use coliforms counts indication of fecal contamination (23).

Oysters are filter-feeding organisms capable of accumulating microorganisms in high concentrations. In fact, according to Nunes and Parsons (24), feeding oysters filter the surrounding water at a rate of 2 to 5 liter/hour eventually assimilating all the biotic and abiotic contaminants present in their environment.

Cerutti and Barbosa (10) have shown that bacterial selection in mollusks is related to factors such as the bacteria's adaptation to the marine environment and resistance to enzymatic degradation as well as the use of the host's gut content as a source of nutrients.

Hagler et al. (18), however, proposed the quantification of Enterococcus spp. instead of coliforms for epidemiological studies, mainly because they are resistant to a number of adverse environmental conditions, such as high salinity, dehydration, pollution with detergents and disinfectants, freezing, low $\mathrm{pH}$ values and moderate thermal treatment. Another important feature of Enterococcus spp. is the ability to produce bacteriocins, a group of toxic proteins to other bacteria (1).

This study was designed 1) to estimate the Most Probable Number (MPN) of total (TC) and fecal (FC) coliforms and Enterococcus spp. in oysters (Crassostrea rhizophorae) collected from a natural oyster bed in the estuary of Cocó river (Fortaleza, Brazil); 2) to evaluate the correlation between the

*Corresponding author. Mailing address: Instituto de Ciências do Mar, LABOMAR, Universidade Federal do Ceará. Av. da Abolição 3207. 60165-081, Fortaleza, CE, Brasil. Tel.: (+5585) 242-6422. Fax: (+5585) 242-8355. E-mail: regine@1abomar.ufc.br 
estimates of TC and FC, and between the estimates of TC and Enterococcus spp. isolated from oyster muscle tissue (including the intervalve liquid); 3) to assess the correlation, if any, between these bacteria and environmental variables, such as temperature, salinity and $\mathrm{pH}$; 4) to identify strains of Enterococcus spp. isolated from the oysters, and to test their ability to produce a bacteriocin-like inhibitory substance using a strain of Escherichia coli (ATCC 25922) as a testing organism.

\section{MATERIALS AND METHODS}

The oysters were collected from a well known and often exploited natural oyster bed in the estuary of Cocó river (Fortaleza, Ceará, Brazil) (Fig. 1), located $200 \mathrm{~m}$ from the river's mouth between latitudes $03^{\circ} 46^{\prime} \mathrm{S}$ and $03^{\circ} 47^{\prime} \mathrm{S}$.

Test samples consisted of whole oyster muscle, that is, the internal muscle and the intervalve liquid. Temperature and salinity of the sampling site were measured in situ with a thermometer (Incoterm, Brazil) and a refractometer (Atago S/ Mill-E, Japan), respectively. Thirty water samples were collected and transported to the laboratory in $500 \mathrm{ml}$ amber bottles placed inside an isothermal box for $\mathrm{pH}$ measurement with a $\mathrm{pHmeter}$ (Micronal B-347, Brazil).

Thirty samples of 10 specimens each (total of 300) were collected between March and October, 2002. All oysters were collected during low tide and transported in isothermal boxes to the microbiology laboratory at Instituto de Ciências do Mar, Universidade Federal do Ceará, for microbiological testing.

The oysters were washed with tap water and opened aseptically. Samples weighing $50 \mathrm{~g}$ were homogenized in a blender with $450 \mathrm{ml}$ of sterilized saline solution $(0.85 \%)$ each, corresponding to a $10^{-1}$ dilution. The same solution was used for making the other tested dilutions $\left(10^{-2}\right.$ to $\left.10^{-6}\right)$.

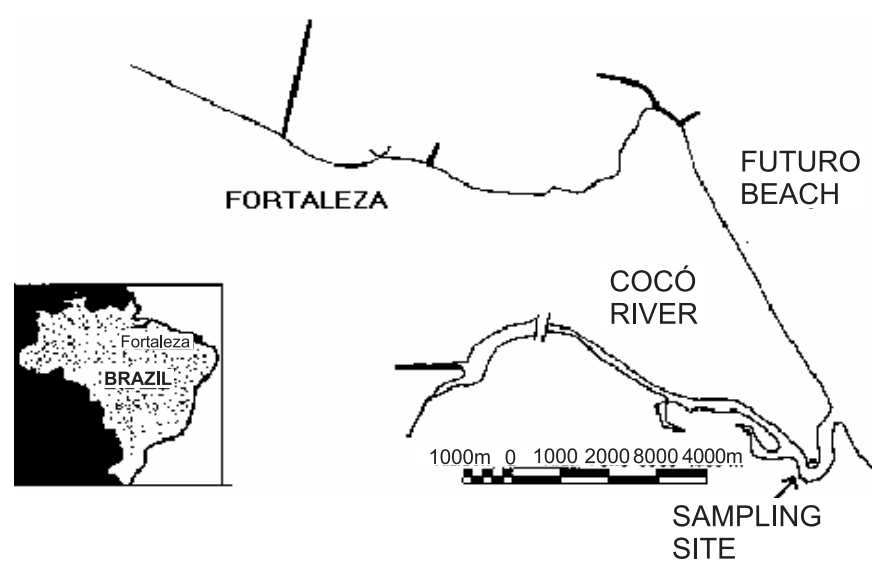

Figure 1. Map of the study area, indicating the oyster (Crassostrea rhizophorae) sampling site at Cocó river's estuary, Ceará State, Brazil.
The most probable number (MPN) of TC was estimated by the 5-tube method using Lauryl Tryptose broth (Difco, USA) incubated at $35 \pm 0.5^{\circ} \mathrm{C}$ and confirmed in brilliant Green Lactose bile broth (Difco, USA) also at $35 \pm 0.5^{\circ} \mathrm{C}$. The FC (or thermotolerant coliforms) counts were estimated after incubation at $44.5 \pm 0.2^{\circ} \mathrm{C}$ in EC medium (Difco, USA) (15). Estimates of TC and FC were based on the MPN table, as described by Garthright (17).

The estimate for the MPN of Enterococcus was determined with the 3-tube MPN technique described in Bergey's manual (8), using azide dextrose broth (Difco, USA) and m-Enterococcus agar (Difco, USA). Typical Enterococcus colonies isolated from m-Enterococcus agar were submitted to confirmation tests through culture in Brain Heart Infusion broth (Difco, USA) incubated at $35^{\circ} \mathrm{C}$ for $18-24$ hours $(14,30)$.

The bacteriocin-like inhibitory substance production capacity of the Enterococcus strains isolated from the oyster samples was verified using Gratia's technique, as described by Kekessy and Piguet (20), using Escherichia coli ATCC 25922 as indicator microorganism.

Strains of Enterococcus cultured in BHI broth (Difco, USA) were spotted onto Trypticase Soy agar (Difco, USA) and incubated at $35^{\circ} \mathrm{C}$ for $24 \mathrm{~h}$. Two microliters of these broths were spotted onto Trypticase Soy agar (Difco, USA) and after incubation at $35^{\circ} \mathrm{C}$ for $24 \mathrm{~h}$, surface growth was killed by exposure to chloroform vapors ( $5 \mathrm{ml}$ added to inverted lid). After $10 \mathrm{~min}$ an overlay of BHI soft agar (1\%) seeded with indicator microorganism (about $10^{6} \mathrm{CFU} / \mathrm{mL}$ ) was added and incubated at $35^{\circ} \mathrm{C}$ for $24 \mathrm{~h}$. A discernible inhibition halo around the growth of Enterococcus spp. indicated the presence of an inhibitory product.

All findings for MPN of FC and Enterococcus spp. were converted to a $\log$ scale ( $\log 10)$ for the purpose of statistical analysis.

In order to check possible correlations between the estimates of FC, TC and Enterococcus, and between them and the physico-chemical parameters (temperature, salinity and $\mathrm{pH}$ ), the Pearson's coefficient was used with a $5 \%$ statistical significance assessed by ANOVA.

\section{RESULTS AND DISCUSSION}

The estimated MPN values for TC and FC ranged from $<1.8 /$ $\mathrm{g}$ to $>1,600 / \mathrm{g}$ and from $<1.8 / \mathrm{g}$ to $920 / \mathrm{g}$, respectively (Table 1 ). The FC values (7.0/g to $3.0 \times 10^{5} / \mathrm{g}$ ) found by Sanchez et al. (29) in oysters from São Paulo State (Brazil) were higher than the ones observed in the present study. MPN values for Enterococcus spp. in the oyster's muscle and intervalve liquid ranged from $<3$ to $>1,100 / g$, whose log-transformed values are shown in Table 1 . Though the regulations for those microorganisms as to bathing suitability are set up only for marine environments in Brazil (3), the present results provide an indication of the level of contamination at the sampling location. 
Table 1. Most Probable Number (MPN) of Enterococcus spp. and fecal and total coliforms determined in the muscle (including the intervalve liquid) of oysters (Crassostrea rhizophorae) collected from Cocó river's estuary, Ceará State, Brazil.

\begin{tabular}{|c|c|c|c|c|c|c|}
\hline \multirow{3}{*}{ Samplings } & \multicolumn{6}{|c|}{$\mathrm{MPN} / \mathrm{g}$} \\
\hline & \multicolumn{2}{|c|}{ Total Coliforms } & \multicolumn{2}{|c|}{ Fecal Coliforms } & \multicolumn{2}{|c|}{ Enterococcus spp. } \\
\hline & Absolute & $\log$ & Absolute & $\log$ & Absolute & $\log$ \\
\hline 1 & 350 & 2.54 & $<1.8$ & 0.26 & 36 & 1.56 \\
\hline 2 & 430 & 2.63 & 32 & 1.51 & 43 & 1.63 \\
\hline 3 & 540 & 2.73 & 220 & 2.34 & 210 & 2.32 \\
\hline 4 & 1,600 & 3.20 & 220 & 2.34 & $>1,100$ & 3.04 \\
\hline 5 & 120 & 2.08 & 120 & 2.08 & 3 & 0.48 \\
\hline 6 & 32 & 1.51 & $<1.8$ & 0.26 & 43 & 1.63 \\
\hline 7 & 94 & 1.97 & 94 & 1.97 & 23 & 1.36 \\
\hline 8 & 1,600 & 3.20 & 20 & 1.30 & 7.4 & 0.87 \\
\hline 9 & 79 & 1.90 & 49 & 1.69 & 23 & 1.36 \\
\hline 10 & 47 & 1.67 & 47 & 1.67 & 460 & 2.66 \\
\hline 11 & 110 & 2.04 & 110 & 2.04 & 43 & 1.63 \\
\hline 12 & $>1,600$ & 3.20 & 540 & 2.73 & 23 & 1.36 \\
\hline 13 & 240 & 2.38 & 79 & 1.90 & $<3$ & 0.48 \\
\hline 14 & 79 & 1.90 & 23 & 1.36 & 93 & 1.97 \\
\hline 15 & 49 & 1.69 & 17 & 1.23 & 43 & 1.63 \\
\hline 16 & 130 & 2.11 & 33 & 1.52 & 43 & 1.63 \\
\hline 17 & 350 & 2.54 & 9.2 & 0.96 & 3.6 & 0.56 \\
\hline 18 & 240 & 2.38 & $<1.8$ & 0.26 & 210 & 2.32 \\
\hline 19 & 540 & 2.73 & 350 & 2.54 & $>1,100$ & 3.04 \\
\hline 20 & 17 & 1.23 & $<1.8$ & 0.26 & 9.2 & 0.96 \\
\hline 21 & 220 & 2.34 & 220 & 2.34 & $>1,100$ & 3.04 \\
\hline 22 & 1,600 & 3.20 & $<1.8$ & 0.26 & 93 & 1.97 \\
\hline 23 & 920 & 2.96 & 110 & 2.04 & 93 & 1.97 \\
\hline 24 & 23 & 1.36 & 23 & 1.36 & 9.2 & 0.96 \\
\hline 25 & 49 & 1.69 & 3.7 & 0.57 & 14 & 1.15 \\
\hline 26 & 94 & 1.97 & 94 & 1.97 & 75 & 1.88 \\
\hline 27 & 920 & 2.96 & 920 & 2.96 & 460 & 2.66 \\
\hline 28 & $<1,8$ & 0.26 & $<1.8$ & 0.26 & $>1,100$ & 3.04 \\
\hline 29 & $>1,600$ & 3.20 & 1.8 & 0.26 & 23 & 1.36 \\
\hline 30 & 79 & 1.90 & 4 & 0.60 & 43 & 1.63 \\
\hline
\end{tabular}

Programme (EU SQAP) determines that shellfish from a category $A$ area can go for direct human consumption if they contain less than $300 \mathrm{FC} / 100$ per gram of meat. Shellfish from category B areas must not exceed, in $90 \%$ of samples, the limit of $6,000 \mathrm{FC} / 100$ per gram of meat. Such shellfish can only be placed on the market after depuration, relaying or heat treatment by an approved process, in order to meet the category A standards (28). If European standards were used in our study, 7 (23.3\%) oyster samples would be classified in category A and 11 (36.7\%) in category B. Category B oysters would have to go through a depuration process, an unheard-of practice among dealers and restaurants in Ceará.

In a study involving oysters (Crassostrea virginica) from an estuary on the coast of the Mexican Gulf, Burkhardt III and Calci (9) found the concentration of fecal coliforms inside the mollusks to be 4.4 times that of the surrounding water. Pommepuy et al. (27) explain this fact by suggesting that the cultivability of E. coli and other enterobacteria is better preserved when the microorganisms are ingested by mollusks than when they are exposed to sunlight in a marine environment, a fact which may account for the great differences observed in bacterial counts.

Furthermore, Machado et al. (23) suggest that the concentration of fecal coliforms in the soft tissues and intervalve liquid of oysters grown for commercial purposes is a more appropriate quality criterion than FC counts of the surrounding water.

The species Enterococcus faecalis was observed much more frequently $(68.12 \%)$ than any other Enterococcus species, including E. durans (3.12\%), E. sulfureus $(3.12 \%)$, E. hirae $(1.25 \%)$ and other unspecified types $(24.38 \%)$. Only one strain $(E$. faecalis) out of 121 Enterococcus strains tested for a bacteriocin-like inhibitory substance production capacity yielded a positive result, inhibiting the growth of the testing organism (Escherichia coli ATCC 25922).

Lauková et al. (21) provided experimental confirmation of

High indices of fecal contamination were detected in Cocó river's waters by Vieira and Façanha (31), a result which confirms the present findings.

The standards of Resolution 12/2001, issued by the Brazilian National Sanitary Surveillance Agency (ANVISA) (2), regulates in natura bivalves not meant for raw table consumption, but no mention to fecal coliforms limits is made. Even though current Brazilian legislation does not regulate raw bivalves, it is possible to make comparisons with other countries' legislation. For example, the European Union Shellfish Quality Assurance growth inhibition of Gram (+) bacteria by bacteriocins produced by Enterococcus faecium.

In an analysis of 92 Enterococcus strains isolated from piglings' feces, DuToit et al. (13) observed only four E. faecalis strains with an inhibitory activity against other Enterococcus spp. All test bacteria used in the present study belonged to the Enterococcus genus.

During the study period the water temperature in the estuary of Cocó river was within the range expected for a tropical environment, varying between $27^{\circ} \mathrm{C}$ and $32^{\circ} \mathrm{C}$. Pinheiro- 
Joventino and Lima-Verde (26) reported temperatures in the range $28^{\circ} \mathrm{C}-32^{\circ} \mathrm{C}$ for the same area, with the highest values occurring in the last months of the year.

The $\mathrm{pH}$ values observed in the estuary of Cocó river ranged between 6.4 and 8.0. In a study of the nearby estuary of Pacoti river, Oliveira (25) found $\mathrm{pH}$ values in the range $7.3-9.3$, with the highest values observed in the dry season and around the onset of the rainy season.

The salinity in the estuary of Cocó river varied between $0 \%$ o and $36 \%$, the lowest reading occurring on a rainy day. The natural oyster bed from which our samples were collected is heavily influenced by the tides. In fact, Ferguson et al. (16) found that in estuaries around Sydney (Australia) reduced rainfalls and stronger tides cause the salinity to increase.

In many countries, the extraction, harvest and culture of bivalves are controlled by water quality analysis. However, the level of coliforms may be affected by factors such as currents, winds and rain occurring in the vicinity of the estuary (22). Thus, though it may be useful as an additional information, the bacteriological quality of the water should not be employed as the main parameter in the regulation of activities in mollusk culture, but nevertheless it ought to be used as complementary data.

In 1991, the European Union's Council unified regulations regarding the production and marketing of bivalve mollusks in order to provide consumers in all member countries with the same level of food safety and to ensure the free circulation within EU of such products. To this effect, EU established a category system for shellfih production areas based on product analysis, whereas in the United States, Chile and Brazil, food safety regulations are based on standards provided by water analysis $(4,5,6,11)$.

The MPN values for FC and Enterococcus were not statistically correlated $(\mathrm{p}<0.05)$. A direct correlation between FC and TC indices was found, a result which might be expected since the former is a subgroup of the latter.

No statistically-significant correlation was found between the concentrations of TC, FC and Enterococcus in the oyster samples and the physico-chemical parameters (temperature, salinity and $\mathrm{pH}$ ) observed in the environment. This may be due to their low level of variability.

Considering the importance of oysters as a mangrove fishery resource in Brazil and following the EU example, the authors recommend the adoption of the quantification of fecal bacteria present in the muscle and intervalve liquid of oysters as a standard parameter in the quality assessment of commerciallycultivated oysters.

Since oysters are preferably consumed raw and are highly valued on the Brazilian market, a clear and specific paragraph should be added to Brazilian food safety regulations to impose limits to the concentration of fecal coliforms on their muscle and intervalve liquid.

\section{RESUMO}

\section{Bactérias de origem fecal contaminantes de ostra Crassostrea rhizophorae, oriundas do estuário do Rio Cocó, Estado do Ceará, Brasil}

O objetivo deste trabalho foi avaliar a qualidade microbiológica da ostra de mangue (Crassostrea rhizophorae) originária de um criadouro natural no estuário do Rio Cocó, Fortaleza, Ceará, Brasil. Para isso, foram realizadas as estimativas do Número Mais Provável (NMP) de Coliformes Totais (CT) e de Fecais (CF) e de Enterococcus spp. Os valores encontrados para CT e CF no músculo (com líquido intervalvar) variaram de $<1,8$ a $>1.600$ e $<1,8$ a 920 por grama, respectivamente. O valor do NMP de Enterococcus spp. variou de $<3,0$ a $>1.100 / g$. Não houve correlação entre os parâmetros físico-químicos (temperatura, salinidade e $\mathrm{pH}$ ) da água na área do criadouro e os níveis de contaminação encontrados nas ostras. Somente houve correlação entre os valores de CT e CF. Cepas de Enterococcus spp. foram isoladas e submetidas a testes bioquímicos para identificação das espécies e, posteriormente, foram testadas para verificar a produção de substância inibitória semelhante à bacteriocina utilizando a cepa-teste Escherichia coli ATCC 25922. De um total de 121 cepas de Enterococcus spp. testadas apenas uma, E. faecalis, apresentou atividade inibitória.

Palavras-chave: ostras, coliformes fecais, enterococos, bacteriocinas

\section{REFERENCES}

1. Alcamo, I.E. Bacterial genetics. Fundamentals of microbiology Benjamim-Cummings Publishing, New York, 1994. 916p.

2. Brasil. Agência Nacional de Vigilância Sanitária - ANVISA Resolução - RDC n ${ }^{\circ} 12$, de 2 de janeiro de 2001. Regulamento técnico sobre os padrões microbiológicos para alimentos. Diário Oficial [da] República Federativa do Brasil, Brasília, DF, 10 janeiro de 2001.

3. Brasil. Conselho Nacional do Meio Ambiente - CONAMA. Resolução $n^{\circ} 274$, de 29 de novembro de 2000. SEMA, Brasília, 2000.

4. Brasil. Ministério da Agricultura. DIPOA. DIPES. 1981. Inf. 376/ 81. Processo MA-11/00214/81.

5. Brasil. Ministério da Agricultura. DIPES. 1988. Inf. 097/88. Processo MA-24/0011881/88.

6. Brasil. Ministério da Agricultura. DIPES. 1991. Papeleta interna 036/91 de 28 de novembro de 1991.

7. Brasil. Ministério da Saúde. Portaria MS n 451, de 19 de setembro de 1997. Aprova o regulamento técnico princípios gerais para estabelecimento de critérios e padrões microbiológicos para alimentos. Diário Oficial [da] República Federativa do Brasil, Brasília, DF, 27 setembro de 1997.

8. Brenner, D.J. Enterobacteriacea. In: Krieg, N.R.; Holtz, J.G. (ed.) Bergey's manual of systematic bacteriology. Williams \& Wilkins, Baltimore, 1984. p.409-423.

9. Burkhardt III, W.; Calci, R.C. Selective accumulation may account for shellfish-associated viral illness. Appl. Environ. Microbiol., 66(4): 1375-1378, 2000. 
10. Cerutti, R.L.; Barbosa, T.C.P. Flora bacteriana heterotrófica em ostras (Crassostrea rhizophorea) e águas da Baía Norte, Ilha de Santa Catarina, Brasil. Rev. Microbiol., 22: 330-334, 1991.

11. Chile. Ministério da Economia, Fomento e Reconstrução do Chile. Serviço Nacional de Pesca e Controle de Qualidade. Programa de Sanitização de Moluscos Bivalves. Diretriz de 15 de junho de 1988.

12. Cook, D.W.; Burkhardt III, W.; DePaola, A.; McCarthy, S.A.; Calci, K.R. Molluscan shellfish: oyster, mussels and clams. In: Downes, F.P.; Ito, K. (ed.). Compendium of Methods for the Microbiological Examination of Foods. $4^{\text {th }}$ ed. APHA, Washington, 2001, p.507514.

13. Du Toit, M.; Franz, C.M.A.P.; Dicks, L.M.T.; Holzapfel, W.H. Preliminary characterization of bacteriocins produced by Enterococcus faecium and Enterococcus faecalis isolated from pig faeces. J. Appl. Microbiol., 88: 482-494, 2000.

14. Facklam, R.R.; Sahm, D.F.; Teixeira, L.M. Enterococcus. In: MURRAY, P.R. (ed.). Manual of Clinical Microbiology. $7^{\text {th }}$ ed. ASM, Washington, 1999, p.297-305.

15. Feng, P.; Weagant, S.D.; Grant, M.A. Enumeration of Escherichia coli and the coliform bacteria. Sept. 2002. In: Food and Drug Administration - FDA/CFSAN. Bacteriological Analytical Manual on line. Jan. 2001. Disponível em: <http://www.cfsan.fda.gov/ ebam/ bam-4.html> Acesso em: 14 de janeiro de 2003.

16. Ferguson, C.M.; Coote, B.G.; Ashbolt, N.J.; Stevenson, I.M. Relationships between indicators, pathogens and water quality in an estuarine system. Water Research, 30(9): 2045-2054, 1996.

17. Garthright, W.E. Appendix 2: most probable number from serial dilutions. In: Food and Drug Administration - FDA/CFSAN. Bacteriological Analytical Manual on line. FDA/CFSAN. Jan. 2001. Disponível em: <http://www.cfsan.fda.gov/ ebam/bam-a2.html>. Acesso em: 10 de junho de 2002.

18. Hagler, A.N.; Mendonça-Hagler, L.C.; Santos, E.A.; Farage, S.; SilvaFilho, J.B.; Schrank, A. Microbial pollution indicators in brazilian tropical and subtropical marine surface waters. Sci. Total Environ., 58: 151-160, 1986.

19. José, V.F. Bivalves e a segurança do consumidor. São Paulo, 1996, 182p. (Dissertação de Mestrado. Ciência Ambiental. USP).

20. Kekessy, D.A.; Piguet, J.D. New method for detecting bacteriocin production. Appl. Microbiol., 20(2): 282-283, 1970.
21. Lauková, A.; Mareková, M.; Javoski, P. Detection and antimicrobiol spectrum of a bacteriocin-like substance produced by Enterococcus faecium CCM 4231. Lett. Appl. Microbiol., 16: 257-260, 1993.

22. Machado, I.C.; Koga, S.M.; Woioechovsky, E.; Gelli, D.S. Estudo da ocorrência de contaminação orgânica no estuário da Cananéia - SP, Brasil, como subsídio para a extração, manejo e cultivo da ostra do mangue (Crassostrea brasiliana). 1 - Avaliação da qualidade da água. Hig. Aliment., 14(72): 66-75, 2000.

23. Machado, I.C.; Paula, A.M.R.; Buzzo, A.; Jakabi, M.; Ristori, C.; Sakuma, H. Estudo da ocorrência de contaminação orgânica no estuário da Cananéia, como subsídio para a extração, manejo e cultivo da ostra do mangue (Crassostrea brasiliana). 2 - Análise da ostra (tecidos moles e líquido intravalvar). Hig. Aliment., 15(83): 44-48, 2001.

24. Nunes, A.J.P.; Parsons, G.J. Dynamics of tropical coastal aquaculture systems and the consequences to waste production. World Aquac., 29(2): 27-37, 1998.

25. Oliveira, A.M.E. Composição e distribuição ecológica da ictiofauna no estuário do Rio Pacotíl Cearál Brasil. Fortaleza, 1993, 149p. (Tese, professor titular. Departamento de Biologia. UFC).

26. Pinheiro-Joventino, F.; Lima-Verde, N.G. Ocorrência e distribuição de macroalgas no estuário do rio Cocó, Fortaleza, Brasil. Arq. Cienc. Mar., 27: 83-89, 1988.

27. Pommepuy, M.; Utin, M.B.; Derrien, A.; Gourmelon, M.; Colwell, R.R.; Cormier, M. Retention of enteropathogenicity by viable but nonculturable Escherichia coli exposed to seawater and sunligh. Appl. Environ. Microbiol., 62(12): 4621-4626, 1996.

28. Rodgers, C.J. The NSW Shellfish Quality Assurance Program: an operational review. Final Report, Jan. 2001, 123p.

29. Sanchez, P.S.; Stoppe, N.C.; Zanoli, M.I.; Martinez, S.C.G.L.; Ostini, S.; Segamarchi, A.L.; Almeida, G.L. Caracterização da qualidade microbiológica de águas marinhas e moluscos bivalves do litoral norte do estado de São Paulo. XVI Congresso Brasileiro de Engenharia Sanitária e Ambiental, Goiânia, 1991, p.430-445.

30. Silva, N.; Junqueira, V.C.A.; Silveira, N.F.A. Contagem de Enterococos. In: Manual de Métodos de Análises Microbiológica de Alimentos. Varela, São Paulo, 1997, p.107-110.

31. Vieira, R.H.S.F.; Façanha, S.H.F. Parâmetros físico-químicos e pesquisa de coliformes totais, fecais e Vibrio parahaemolyticus nas águas do rio Cocó, Fortaleza - Ceará. Cienc. Agron., 25(1-2): 24-31, 1994. 